\title{
農業用ロボッ技術の 研究開発動向
}

宮原佳彦 Sumihiko Miyahara 国立研究開発法人農業・食品産業技術総合研究機構農業技術革新工学研究センター

\section{はじめに}

現在，我が国では急速な少子高齢化が進む中，人口が 減少に転じたとされ，近い将来における労働力不足の懸 念が高まっている，特に，農業分野では，他分野よりも

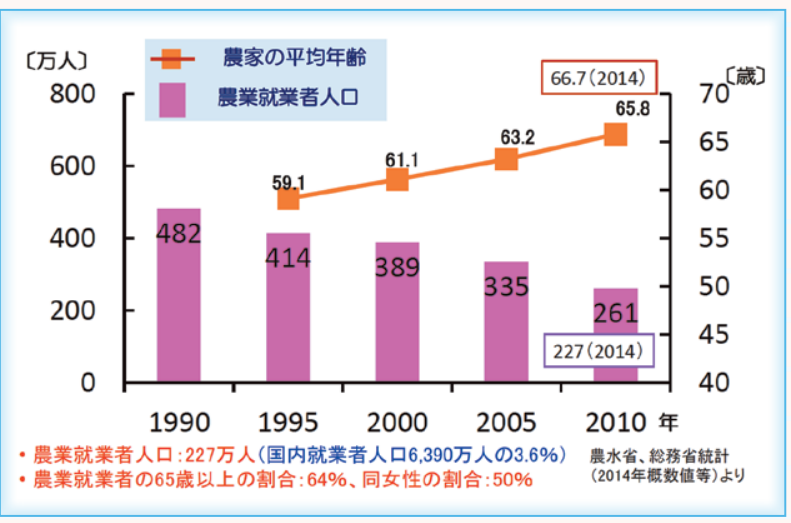

図 1 農業就業人口と平均年齢の推移
更に急激な高齢化と人手不足が進み，既に深刻な状況と なりつつある（図 1)。このため，食料の安定生産や品 質確保も脅かされる状況が迫っていると考元られてい る。 そこで，農林水産省では，ロボット技術や ICT 等 革新的な技術を農業現場に導入し，超省力的で，安定か つ高品質生産を実現する新たな農業，すなわち「スマー 卜農業」の確立を目指す方向性が示されている（図2）。

筆者が所属する国立研究開発法人農業・食品産業技術 総合研究機構 (農研機構) 農業技術革新工学研究セン ター（革新工学センター）では，前記「スマート農業」 を実現するため，企業や地域の協力を得ながら，新技術 の実用化と普及を図ることを目的として，農業用ロボッ トの研究開発を進めている。本稿では，現在の農業用口 ボットの研究開発の動向とともに, 当セン夕をはじめ, 現在進めら机ている農業用ロボット開発と実用化を目指 した取組みについて紹介する。

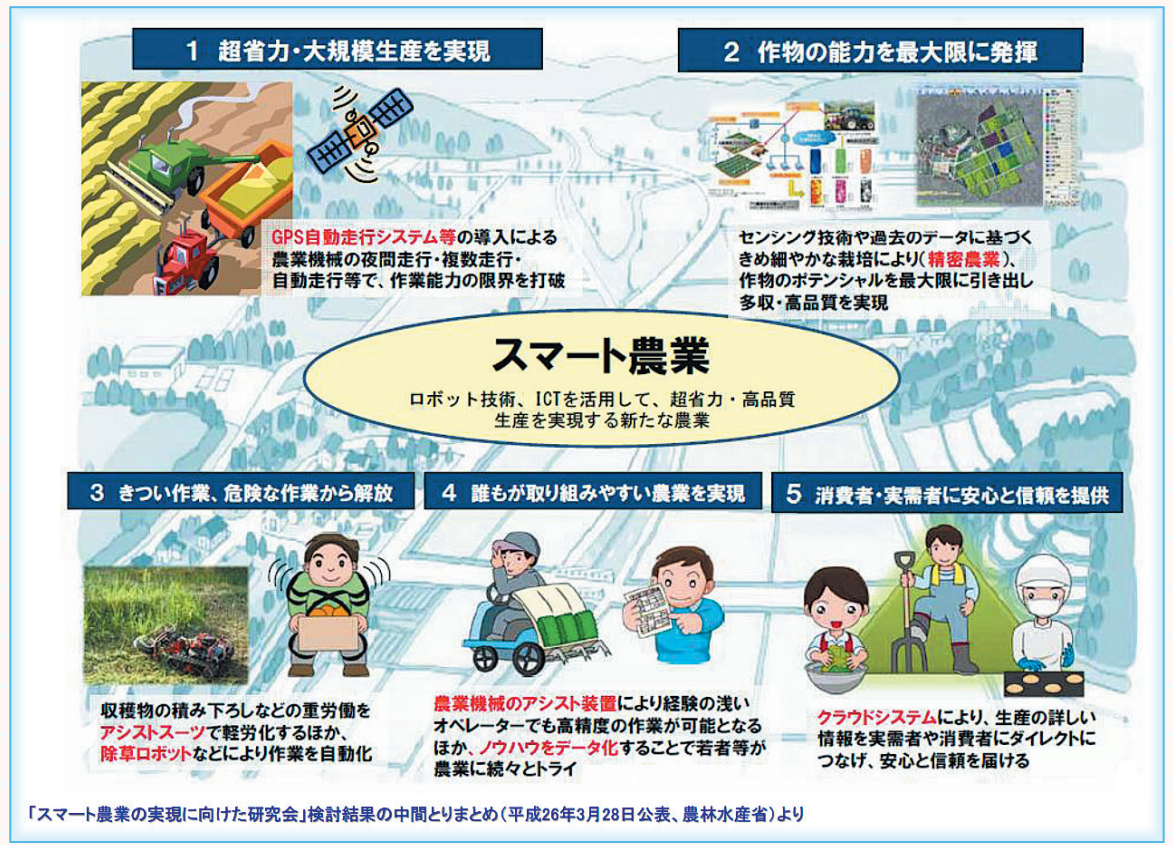

図 2 「スマート農業」のイメージ 
表 1 農業用ロボットの分類・実用化状況

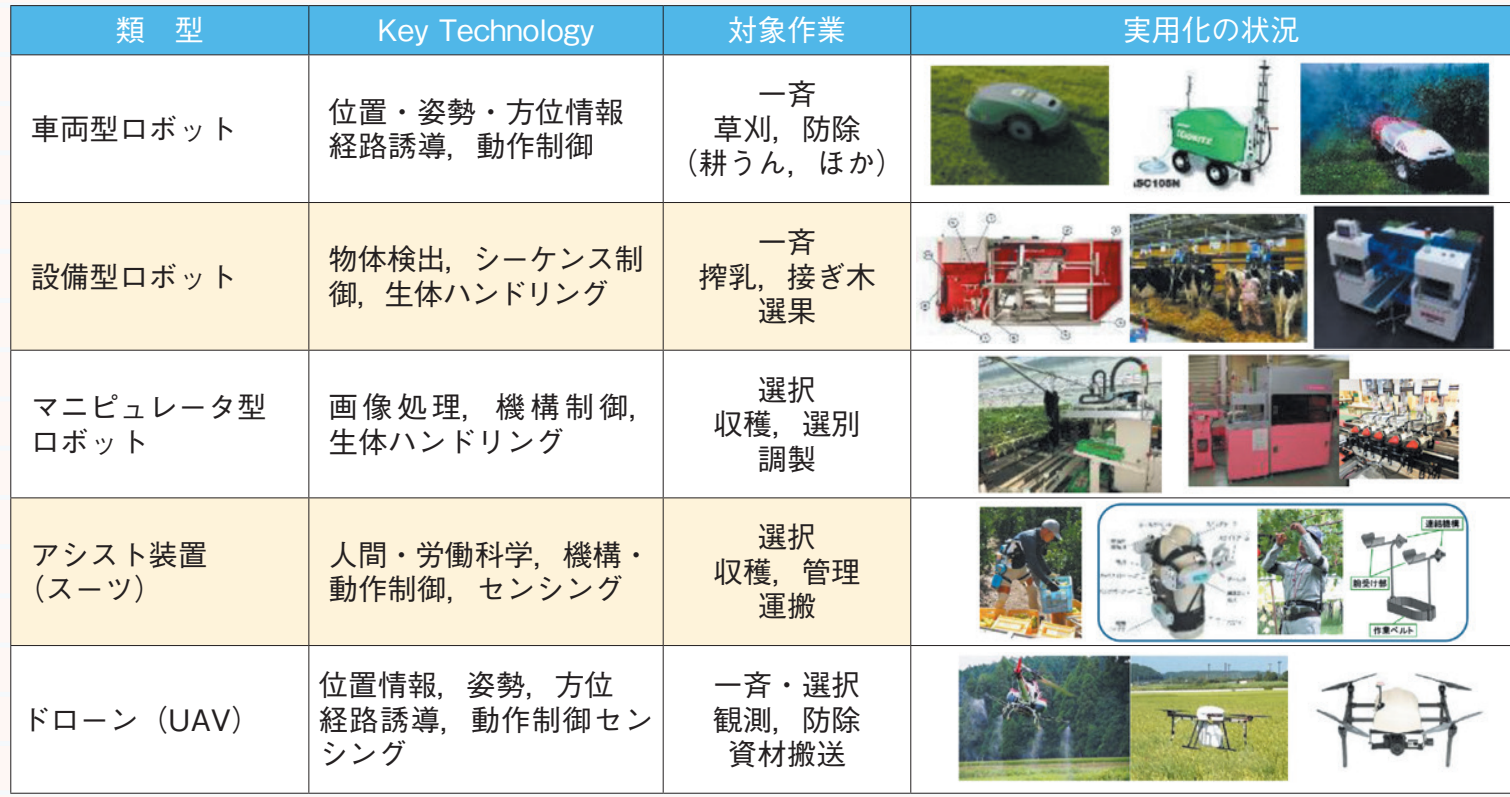

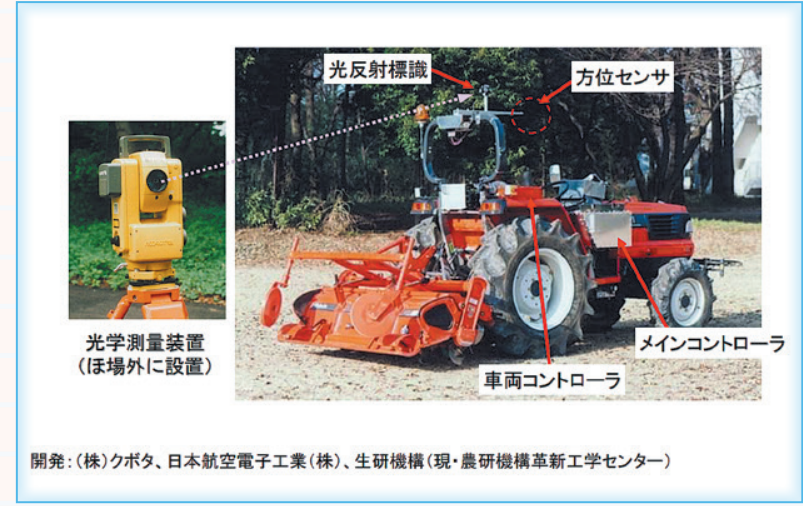

図３＼cjkstart初期のロボットトラクタ（耕うんロボット）

\section{農業用ロボットの分類}

本稿では便宜的に農業用ロボットを表 1 のように, (1)車両型，(2)設備型，(3)マニピュレータ型，(4)アシスト 装置，(5)ドローンの五つに分類し，その中で主なものを 次章以降で紹介する.

\section{3) 車両型ロボット}

トラクタ，田植機，コンバイン等の車輪やクローラ等 で構成される「車両型」の走行部を有し, ほ場（畦畔, 柵等で一定区画に区切られた農耕地）の内外を走行し， それぞれ所定の作業を行う農業機械をほぼそのまま「口 ボット化」したものをここでは「車両型ロボット」とし た。これまでに実用化された例としては，芝刈りロボッ 卜，園芸施設用無人農薬散布機，無人スピードスプレー ヤ等があるが，ロボットトラク夕に関しては，いまだ市 販化には至っていないが，農機メーカからはここ 1〜2 年中に実用化するとの公表がされている.

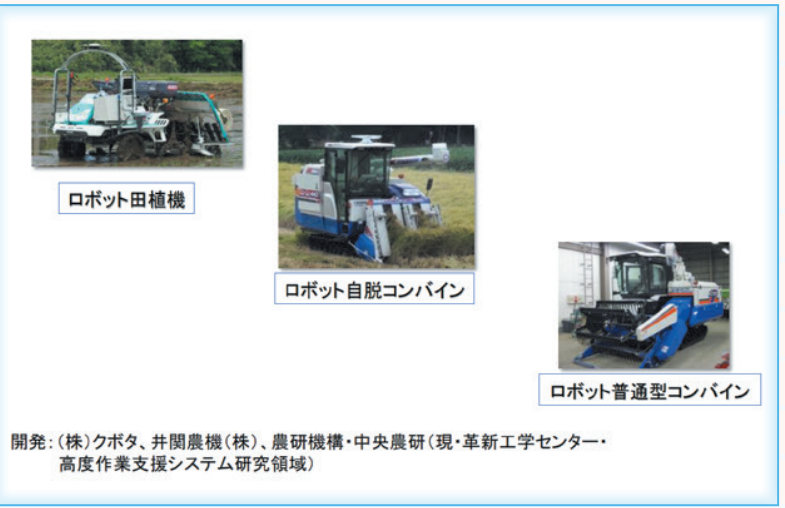

図 4 車両型ロボット（水田作用）

トラクタのロボット化研究の歴史は古く，特別認可法 人生物系特定産業技術研究機構（現在の農研機構・革新 工学センター) の「耕うんロボット（図 3)」は 1990 年 代に研究開発が行われた ${ }^{(1),(2)}$.ロボットトラクタには, 本体の位置, 方位・姿勢，速度等の情報を取得する「航 法センサ」，オペレータに代わって機体を操縦する「自動 操舵・走行制御システム」及び各部を制御する「コントロー ラ」が必要となる。前記「耕うんロボット」では，「航法 センサ」として, 地磁気方位センサ, 光学センサ, GPS (GNSS) 測位システム等が検討されたが，その後，高精 度な RTK-GNSS（Real Time Kinematic-GNSS）装置の 小形・軽量化, 低価格化が進み, 現在検討されている車 両型ロボットの多くは, 同センサとして, 慣性計測装置 (IMU) とRTK-GNSS 装置を併用する例が一般的である. 農研機構中央農業総合研究センター（中央農研，現在 の革新工学センター高度作業支援ステム研究領域）では, 乗用田植機，自脱及び普通型コンバインのロボット化技 術の開発を行った(図 4) ${ }^{(3)}$ 。これらのロボットは, 前記「航 法センサ」を搭載し，ベース機の走行・操舵装置及びエ 


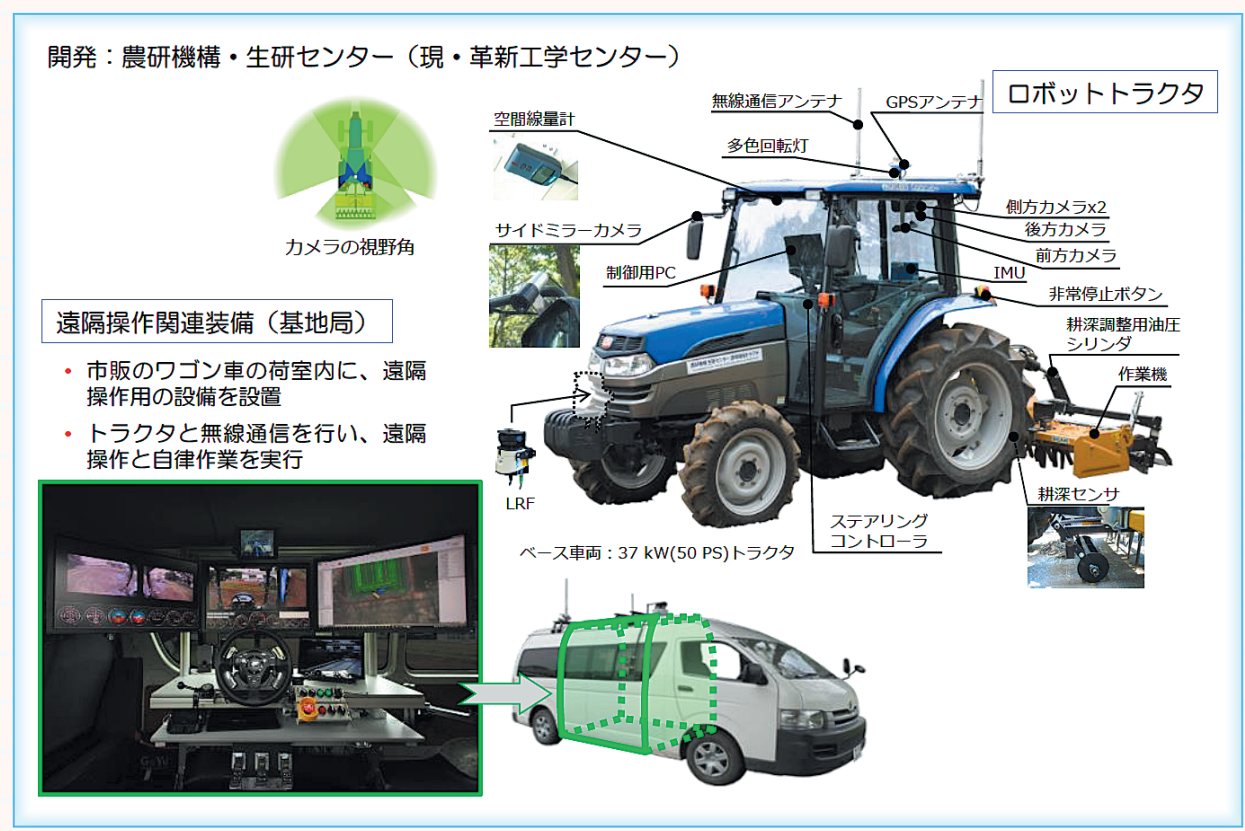

図 5 ロボット農用車両遠隔運用システム

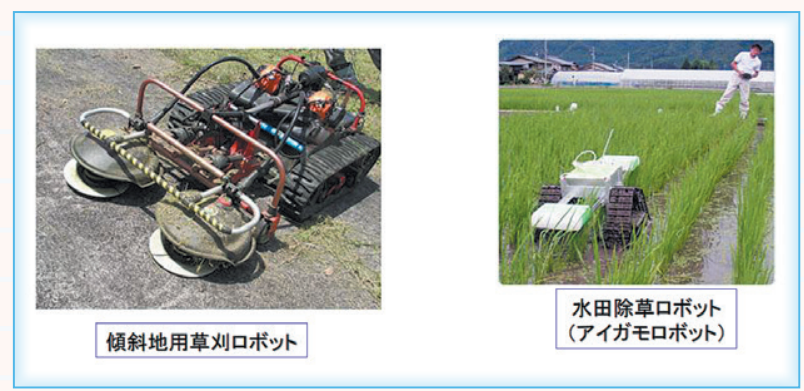

図 6 車両型ロボット開発事例

ンジン等を制御する「自動操舵・走行制御システム」と それらを自動制御するコントローラ (小形 PC) を搭載し ている．開発機の航法センサは，異なるロボット同士で 相互利用できる仕様であり，ロボット内外との制御信号 や情報通信の規格は国際規格で統一・共通化されている.

更に, 農研機構·生物系特定産業技術研究支援センター (生研センター, 現在の革新工学センター) では, 複数の ロボット農用車両を遠隔監視し, 少人数で運用するシス テムの開発に取り組んできた。同システムは,「遠隔操縦」 と「自律運転」が可能なロボットトラク夕本体と, 遠隔地 でロボットの監視を行う基地局から成る (図 5) ${ }^{(4)}$. ロボッ トトラクタ本体は，市販中型トラクタがベースで，前記同 様の航法センサ, 自動操舵・走行制御システム及びコン トローラ (PC) に加えて, 遠隔操縦・監視用の小形ビデ オカメラ数台と無線での通信・自動制御機器類を搭載し ている，基地局（図 5）は，遠隔操縦用の運転席と操縦 装置, 画面表示装置 (ディスプレイ類), 音響装置（スピー カ，警報ブザー等)，ロボットの作動状況や位置情報を管 理·制御する PC 等から構成されている. 同システムでは, 遠隔操作でロボットのほ場への移動等を行い，ほ場到着 後は，あらかじめ作成された作業計画経路に基づいて,
オペレータの直接操作なしの自律自動作業を実行する. 同システムでは，現在までに，耕うん，代かき作業を通 常の有人トラクタと同程度の精度で可能であることを確 認しているが，作業能率を考え，構想では，1２名程度 の作業者（オペレータと監視役等）が 2〜 4台のロボット トラクタを操作する機能に拡充していく予定である.

車両型ロボットは以上のほか,「傾斜地用除草ロボッ 卜」や「水田除草ロボット」等が開発中である（図 6). 「傾斜地用除草ロボット」は，無線による遠隔操作で水 田等の畦畔上の雑草の草刈作業を行うもので, 走行部と 刈取部は電動で，従来のエンジン駆動式草刈ロボットよ りも小形・軽量で, 最大 45 度の急傾斜地でも安定作業 ができる性能を持つ。農研機構・近畿中国四国農業研究 センター（現・西日本農業研究センター）が, 大学, 企 業及び研究機関と共同で開発してきたもので, 現在実用 化の検討が行われている。「水田除草ロボット」は，水 田内の稲株の列間（条間）をクローラ式走行部が繰返し 走行する際に, 雑草が損傷する作用により, 水田内除草 を行う。駆動は電動モー夕で, 水稲有機栽培で著名な「 イガモ栽培」になぞらえて「アイガモロボット」とも呼 ばれる，現在，公的研究機関，大学及び民間企業が共同 で開発中であり,近い将来での実用化が検討されている。

\section{マニピュレータ型ロボット}

人が手や簡単な道具を使って行う作業を代わりに行う ロボットを「マニピュレータ型ロボット」と分類する. トマトやイチゴ等を収穫するロボットがこれに該当する。

トマト収穫ロボットの開発は 1992 年頃から大学が中 心となり行われた。同ロボットは，マニピュレータとエ 


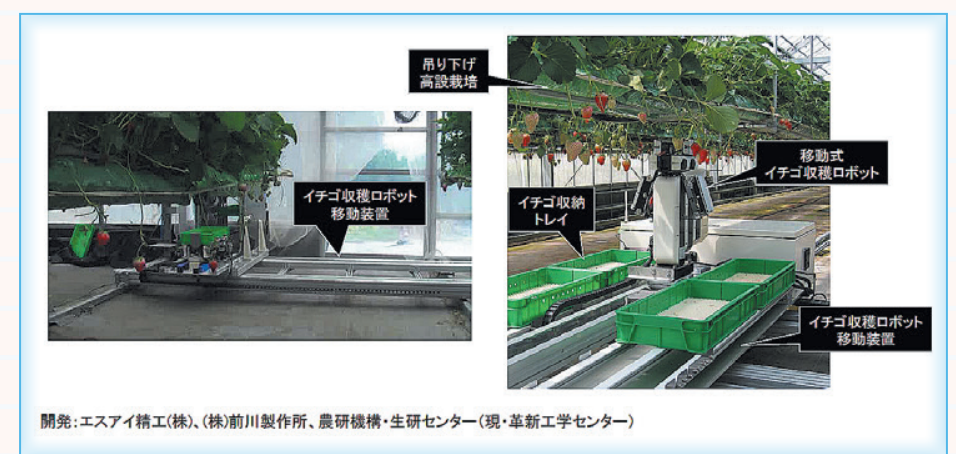

図７イチゴ収穫ロボット（移動式）

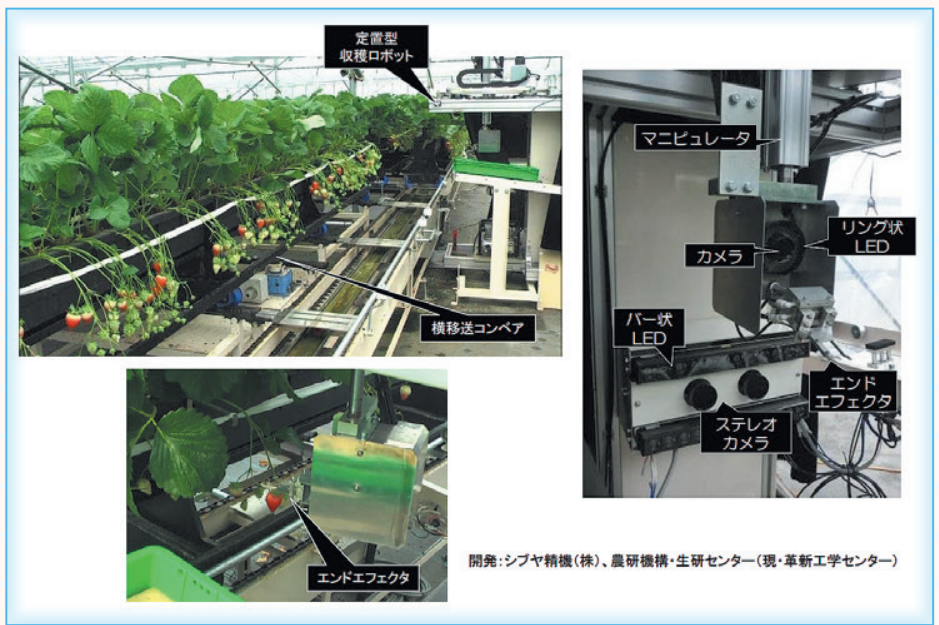

図 8 「循環移動式栽培装置」と「定置型イチゴ収穫ロボット」

ンドエフェクタ及びステレオカメラによる画像処理装置 等を組み合わせた構成であった。同ロボットは，画像処 理装置の視野内の複数果実の中から，果実の色等に関す る情報に基づいて熟度を判別し，採果する機能を有して いたが, 人が行う作業を代行するまでには至らなかった。 ほかにも，ほぼ同様の技術を応用したナス収穫ロボット （1997 年頃）やキャベツ収穫ロボット（1990 年頃）等 の例がある。

生研センターでは，民間企業との共同開発により，イ チゴの収穫ロボットの開発に取り組んだ（図 7) ${ }^{(5)}$ 。当 初の開発コンセプトは，1)イチゴの栽培施設内で，収穫 適期の果実のみ収穫する，(2)主に夜間に稼動する，(3)果 柄（果実から主茥につながる柄の部分）を切断し収穫す る，(4)り下げ式高設栽培方式（図 7 の栽培装置）を 対象とする等であった。開発されたイチゴ収穫ロボット は，円筒座標型マニピュレータとその先端に設置された エンドエフェクタ（果柄を把持し, 所定の部位で切断し, 果実をトレイに収納する)，果実検出部（LED 照明と複 数の CCD カメラで構成される視覚装置) 及び収穫果実 を収納するトレイ，同トレイの収納部及び施設内を移動 する装置等で構成される。移動装置は, 施設内の作業通 路上に設置したレールに沿って移動する方式で，適期収 穫割合が約 $70 \%, 1$ 果収穫所要時間約 9 秒とおおむね
目標を達成したが，移動装置・設備等を含む導入コスト が大きく，実用化には至らなかった。

一方，栽培ベッドを施設内で移動し循環させること で，慣行のつり下げ式高設栽培の約 2 倍の密植栽培が できる「循環移動式栽培装置」が開発された。同装置は, 栽培ベッドが縦方向と横方向に順次移動し，同じ位置を 循環する機構であり，作業者は定位置で定植や収穫など を行うことができる。このため, 定置型の収穫ロボット が開発された (図 8) ${ }^{(6)}$. 同ロボットは,マニピュレータ, エンドエフェクタ，果実検出部及びトレイ収容部等の主 要構成は移動式と同様であるが, 移動装置がなく，定位 置に固定される。性能試験の結果，夜間運転で適期収穫 割合 42〜 79\%の作業が可能であり，果実の損傷も人手 と大差なかった。 また，ロボットが定位置に設置されて いるため，マシンビジョン範囲内を遮光することで昼間 も円滑な作業ができる. 以上の結果を受け, 同ロボット は2013 年度に実用化された。

生研センターでは，イチゴのパッケージセンタ向けの イチゴパック詰めロボットの開発も行っている ${ }^{(7)}$. 同ロ ボットは, 選果ラインの終端に組み込まれ，ライン上で 階級別に選別された果実を平詰めソフトパックに詰め込 む作業を行うマニピュレータ型ロボットの一種である (図 9)。パック詰めユニット, 搬送容器ユニット, 出荷 


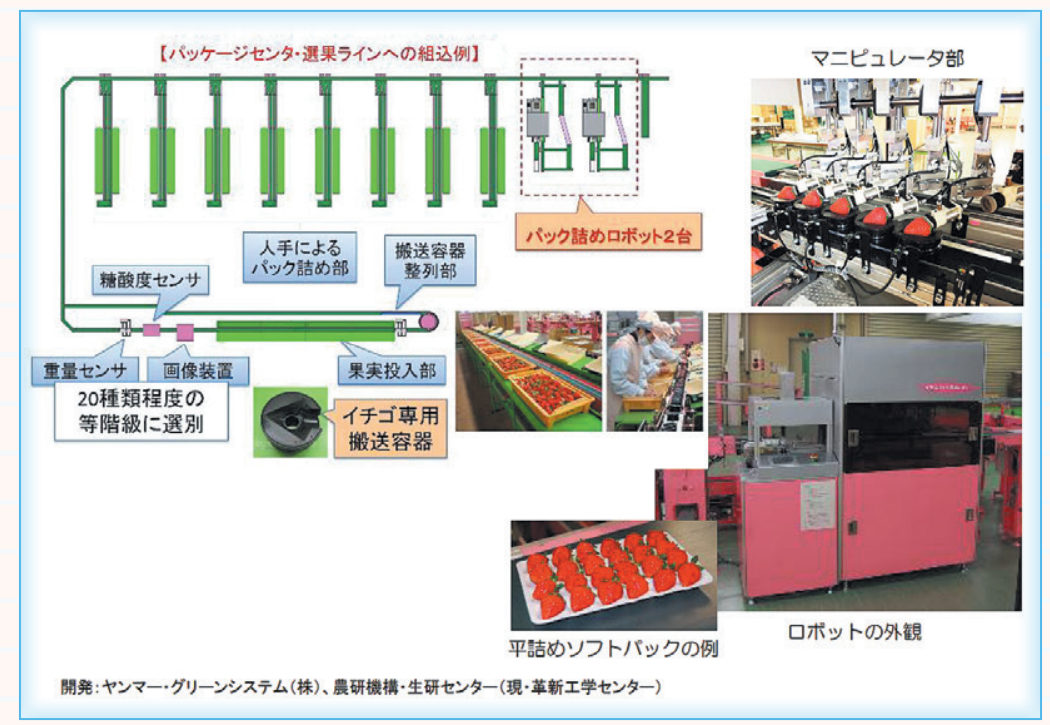

図 9 イチゴパック詰めロボット

容器ユニットで構成され，1 回の動作で複数のイチゴ果 実（図 8 の構成では 6 個以内）を同時に搬送容器から 吸い上げ，平詰めソフトパックに詰める。性能試験の結 果, 同ロボットは, 1 パック当りの作業時間 45〜 59 秒と, 人に比べて約 $40 \%$ の能率を向上できた。 なお，吸着成 功割合 $99 \%$ 以上で，一部果実姿勢の手直しが必要な場 合もある。これらの結果を受け，同ロボットは 2014 年 度に実用化された。

\section{施設型ロボット}

酪農における搾乳や給慨の施設，施設園芸で行われる 各種作業工程の一部若しくは全体を担うロボットを「施 設型ロボット」として分類する。

施設型ロボットの代表的なものに，大規模酪農家で導 入されている㩁乳ロボットがある，同ロボットは，放し 飼い方式の牧場における搾乳施設(ミルキングパーラー) に設置され，同施設に誘導された乳牛をロボット内で静 止させ，光学センサ等で乳頭位置を検出し，㩁乳器を自 動的に着脱して㩁乳を行う。全世界の先進酪農家に普及 しており，農業用ロボットとしては最も普及していると されている。しかし，同ロボットが対応していないつな ぎ飼い方式（日本国内に多い）に対しては，㩁乳ユニッ トが牛の近くまで自動的に搬送される搾乳ユニット自動 搬送装置（呼称：キャリロボ）が，生研センターと企業 により共同開発され，2002 年に実用化された後，現在 までに国内で 350 台程度普及している.

施設園芸分野では，生研センターと農機メーカが共同 開発した接ぎ木ロボットがある。同ロボットは，キュウ リ，スイカ，メロン等のウリ科野菜の接ぎ木苗生産工程 において, 栽培する野菜の苗（穂木，根側を切断）と力 ボチャ等のほかの野菜苗（台木，枝葉側を切断）を切断
部で自動的に接合する作業を行う。接ぎ木苗は，育苗施 設で一定期間生育された後, 苗市場や生産現場に出荷さ れる。同ロボットは，1993 年より市販化され，これま でに国内で 100 台以上が普及している.

\section{その他のロボット}

人力に頼る作業, 例えば, 運送業での荷物の持ち運び, 介護や医療現場での人体の持ち上げや支持等において, 作業者の肉体的負担軽減を目的とした人体装着型の口 ボットや機器の研究開発が近年急速に進んでいる。農業 分野でも, 野菜や果樹等の収穫, 袋詰め肥料の運搬等, 作業者の肉体的負担が大きく, 機械化が進んでいない作 業の負担軽減が強く要望されているため，そのような農 作業時の作業者の負担軽減を目的として，人体装着式の 作業負担軽減装置の研究開発が盛んに行われている。 そ れらには，ロボットやセンサ技術等を利用した高度な制 御を行うタイプからばねや記憶形状合金等を利用した 機械的で簡易な構造のものまで様々な方式が研究されて いる，本稿では，特に，ロボット技術を使用若しくは応 用し，農作業における作業者の負担軽減を目的とした装 置を「農作業アシスト装置」に分類する。

「農業用アシスト装置」の例としては，作業者に装着 し，上半身を支えつつ，両腕と両脚の動きを補助する方 式の装置（呼称：農作業アシストスーツ）がある。同装 置では，コンテナ入りの収穫物（果実や野菜等）の持ち 上げ・運搬作業において腰・膝等への負担軽減や傾斜地 での安定姿勢維持や歩行を容易にすること等を目指して いる.一方, より安価で簡易なアシスト装置としては, 桃・ 柿・ブドウなどの棚仕立ての果樹等において，上向き姿 勢での摘花・摘果・袋かけ等の長時間作業における作業 者の肉体的負担を軽減することを目指した装置の開発が 


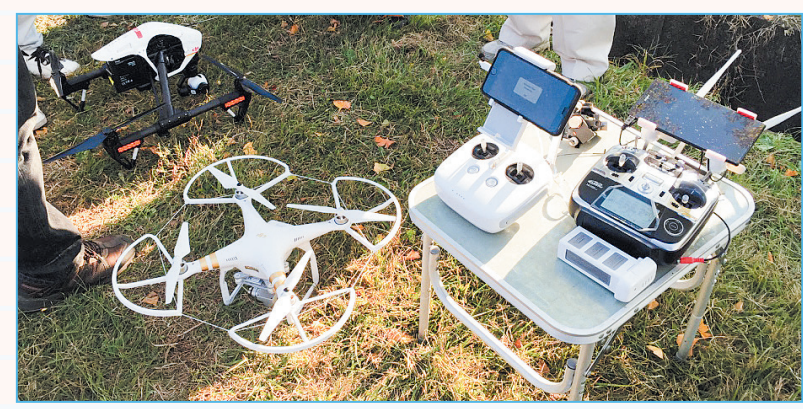

図 10 ドローン (市販機) の例

行われており，市販化された装置も幾つかある.

一方，「ドローン」は，UAV (Unmanned Aerial Vehicle の略）とも呼ばれ，無人で遠隔操作や自動制御 によって飛行する小形の航空機で，特に複数の水平回転 翼を持つ夕イプを指す（図 10）が，これを農業で利用 する技術が注目されている。このため，前記表 1 の分 類にも加えている，利用場面としては，これまで，産業 用無人ヘリ（ラジコンヘリ）を主体に行われてきた水田 等への農薬散布作業に，ドローンを使用するもので，所 定の仕様・性能を持った農薬散布装置を搭載したドロー ンの機種の認定今年度から開始され，また，これに合わ せた新機種も市場に登場するなど，農業現場での本格的 利用が始まりつつある。 また，農薬散布以外にも，農作 物の生育情報の取得，ほ場の遠隔監視，あるいは，害鳥 獣への威嚇等への応用が検討されており ${ }^{(8),(9)}$, 今後の 進展が期待される。

\section{おわりに}

我が国政府は「ロボットによる新たな産業革命」を目 指す取組みを進めており，様々な産業分野において，口 ボット技術，ICT 等を活用した革新的な技術の開発を推 進するとともに，生み出された新技術の速やかな社会実 装を図ることを目指すとしている.このため, 場合によつ ては，規制改革・緩和，技術の標準化の推進など，具体 的な政策も進めるとしている，既に，工業生産現場にお いては，ロボット技術や ICT 等の活用が進んでおり， 国際競争力の源泉ともなっているが，今後は，農業分野 にも，高度な生産技術を導入し，産業としての活性化を 図ることが重要と考えられている。これまで，大学や民 間公的研究機関を中心に行われてきた農業用ロボットの 研究開発も，以上の情勢から，民間企業や農業現場での
取組みが大幅に活発化しており，現場への普及の機運も 日に日に大きくなっている。 今後の展開が大いに期待さ れるところである。

\section{文献}

（1）例元ば，行本 修，松尾陽介，野口 伸，鈴木正肚， “耕うんロボットシステムの開発 (第 1 報), ”農機誌, vol.60 no.3, pp.37-44, May 1998.

（2）例えば，松尾陽介，行本 修，入江康夫，一杉則昭， 野口 伸, “耕うんロボットの航法技術と作業性能（第 l 報),”農機誌, vol.63, no.3, pp.114-121, May 2001.

（3）農研機構・中央農研, “田植えロボット: 無人で施肥・ 移植・除草剂散布, ”研究成果ダイジェスト, https://www.naro.affrc.go.jp/narc/result_digest/ jisedai/seisan/028171.html, 2008.

(4) 紺屋秀之, 山下貴史, 林 和信, 塙 圭二, 中山夏希, 吉永慶太, 窪田陽介, 山田祐一, 市来秀之, 重松健太, 吉野知佳, 西村 洋, 小林 研, 宮原佳彦, “遠隔操 縦および自律運転により除染作業を支援する無人卜 ラク夕,”農研機構・生研セン夕ー, 研究成果情報, http://www.naro.affrc.go.jp/project/results/ laboratory/brain/2012/600d0_01_03.html, 2012.

（5）林 茂彦, 山本聡史, 齋藤貞文, 小林 研, 重松健太, 吉田啓孝，河野 靖，鎌田順三，栗田充隆，“つり下 げ式高設栽培ベッドに対応したイチゴ収穫ロボッ 卜, ”農研機構・生研セン夕ー, 普及成果情報, http://www.naro.affrc.go.jp/project/results/labor atory/brain/2010/brain 10-08.html, 2010.

（6）坪田将吾, 林 茂彦, 山本聡史, 斎藤貞文, 岡崎剛政, 瀬尾 明, 鎌田順三，稲積浩之，P. Rajendra，“循 環移動式栽培装置と連動する定置型イチゴ収穫口 ボット,”農研機構・生研センター, 普及成果情報, http://www.naro.affrc.go.jp/project/results/ laboratory/brain/2013/13 087.html, 2013.

（7）山本聡史, 林 茂彦, 坪田将吾, 落合良治, 田中伸明, 山田久也, “イチゴパック詰めロボットの開発,”農 食工誌, vol.77, no.3, pp.197-209, May 2015.

（8）田中勝千 (編), “農業分野におけるドローン利用の 可能性 I (特集), ”農食工誌, vol.78, no.2, pp.109-121, March 2016.

（9）田中勝千 (編)，“農業分野におけるドローン利用の 可能性 II (特集), ” 農食工誌, vol.78, no.3, pp.191-200, May 2016.

\section{宮原佳彦}

1981 筑波大大学院了(農博). 現職は, 国立研究開発法人農業・食品産業技術 総合研究機構 (農研機構) ・ 農業技術 革新工学研究センター（革新工学セン ター) ・土地利用型システム研究領域 長. 過去に水田，畑，果樹等で使用す る農薬散布機等の研究開発を担当. 近 年は農作業用ロボットを含む新たな農 業機械・装置の研究開発を統括.

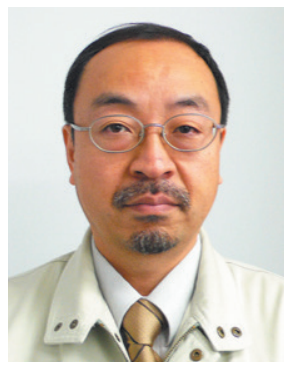

